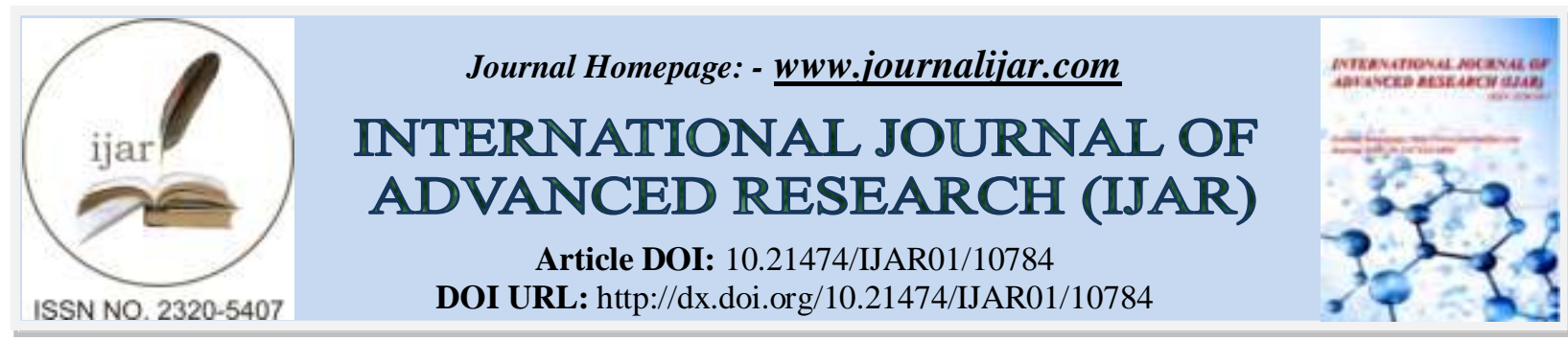

RESEARCH ARTICLE

\title{
RISK ASSESSMENT OF THE EXPOSURE OF SENEGALESE CONSUMERS TO PESTICIDE RESIDUES IN ARTISANALLY PROCESSED SARDINELLA AURITA AND SARDINELLA MADERENSIS PRODUCTS
}

\author{
Ndeye Ndiabe Mbaye ${ }^{1}$, Mbacke Sembene ${ }^{1}$, Jennifer E. Botewa ${ }^{2}$ and Bruno Schiffers ${ }^{2}$ \\ 1. Laboratory of Entomology and Acarology, Department of Animal Biology, GEMGESPOP Team, Faculty of \\ Science and Technology, Cheikh Anta Diop University of Dakar. \\ 2. Gembloux Agro-BioTech/ULiege, Phytopharmacy Laboratory. Passage of Deportees 2 -5030 Gembloux \\ (Belgium).
}

\section{Manuscript Info}

Manuscript History

Received: 10 February 2020

Published: April 2020

Sardinella Aurita, Sardinella

Maderensis, Artisanal Processing,

Dermestes, Pesticide, PSTI
Final Accepted: 12 March 2020

Key words:-

\begin{abstract}
In Senegal, sardinella (Sardinella aurita and Sardinella maderensis) are braised or smoked, salted, and dried to preserve them, resulting in a product called ketiakh. Surpluses and unsold catch are processed into ketiakh and stored, then marketed in Senegal and the sub-region. Pesticides are used to combat insect pests, mainly dermestid beetles (Dermestes spp). This study assessed the sanitary quality of processed sardinella and the risk to consumers exposed to residues of these pesticides. Twenty-five samples of smoked-dried sardinella (ketiakh) were taken from various points along the Senegalese coast. Residues (nature and concentrations) were determined by the PRIMORIS laboratory (Belgium) by combining two multi-residue methods (148 active substances were tested in GC-MS/MS). The results showed the presence of chlorpyrifos, cypermethrin and fenitrothion, at concentrations ranging from 0.011 to $0.310 \mathrm{mg} / \mathrm{kg}$ for chlorpyrifos. The risk of exposure to these three insecticides was evaluated by calculating the predicted short-term intake (PSTI) for a $70 \mathrm{~kg}$ adult and a $20 \mathrm{~kg}$ child during a meal prepared according to a traditional recipe, then compared to the respective acute reference dose and acceptable daily intake values. The calculation of PSTI indicated values reaching $10,000 \%$ of the toxicological reference values. The results of the study therefore indicate that the consumption of artisan-processed $S$. aurita and $S$. maderensis along the Senegalese coast may present a major toxicological risk for both young and adult consumers.
\end{abstract}

Copy Right, IJAR, 2020,. All rights reserved.

\section{Introduction:-}

Smoked-dried sardinella, commonly known as ketiakh, are a substitute for fresh fish and are part of the Senegalese diet. The artisanal processing of these fish products not only plays an economic and social role, but is also culturally important, contributing to the democratization of access to food and generating additional income for coastal populations (GRET, 2005). During storage, processed fish products suffer losses of 30-50\% (Watanabe, 1974) mainly due to infestation by dermestid beetles: Dermestes spp (FAO, 1981; Sembene, 1994) or other beetles such as Necrobia rufipes (FAO, 1981). 
Braised-dried or smoked-dried fish is also attacked by the mite Lardoglyphus konoi in Senegal (Sembene, 1994). This mite is known to cause severe damage to dried or salted fish in Japan and India (Gueye-Ndiaye and Marchand, 1989). Feeding by larvae and adults causes considerable losses and leads to fragmentation of dried products. Loss of quality can also be caused by the presence of insect remains and detritus. To limit losses of their products, processors in Senegal have been using insecticides such as DDT (dichlorodiphenyltrichloroethane) for more than 20 years, Watanabe (1974) drew the attention of consumers to the health risks several decades ago. The results of a preliminary survey in 2011 on the use of pesticides on processed fish products (Mbaye et al., 2013), as well as the results of analyses of pesticide residues in smoked-dried fish (ketiakh) carried out by CERES-Locustox in Dakar, showed the presence of various insecticides in the samples taken. For samples taken on the Great Coast, two organochlorines (lindane and dieldrin), three organophosphorus (parathion, pirimiphos-methyl and chlorpyrifosethyl) and one pyrethroid (permethrin) were detected. For the Small Coast, analyses showed the presence of one organochlorine (lindane), three organophosphorus (parathion, pirimiphos-methyl and chlorpyrifos-ethyl) and one pyrethroid (permethrin) (Mbaye et al., 2012). Based on these results, a study was conducted on several processing sites of smoked-dried fish products (ketiakh) prepared from Sardinella aurita and Sardinella maderensis. The objective was the identification and quantification of pesticide residues on artisan-processed sardinella along the seafront of Senegal, from Saint-Louis to Joal-Fadiouth passing through Kayar, Dakar and Mbour, in order to characterize the potential exposure risk to consumers in Senegal and the sub-region.

\section{Material and Methods:-}

\section{Location of collection sites and sampling:}

Twenty-five samples were taken (from 20 to 26 July 2012) from the five main processing sites in Senegal, taking care to cover the entire seafront (Great Coast and Small Coast) (Map 1). Depending on the availability of products in each of the sites visited, five samples of smoked-dried Sardinella aurita and Sardinella maderensis (ketiakh) were taken from various stalls, randomly selected. The sites of Mbalene to Mbour, Khelcome to Joal-Fadiouth and Kayar are located in the Thies region (Mbour and Joal are part of the Small Coast while Kayar is part of the Great Coast). The site of Guet Ndar is located in the Barbary language in Saint-Louis of Senegal where processing activities are carried out on the sea side as well as on the Senegal river side. Guet Ndar or fishermen's quarter is one of the most important fishing ports in West Africa (ANSD, 2010). The Diamagueune-Bata or DGB site is located in the locality of Diamagueune, commune of East Rufisque (Rufisque department, Dakar region (ANSD, 2009).

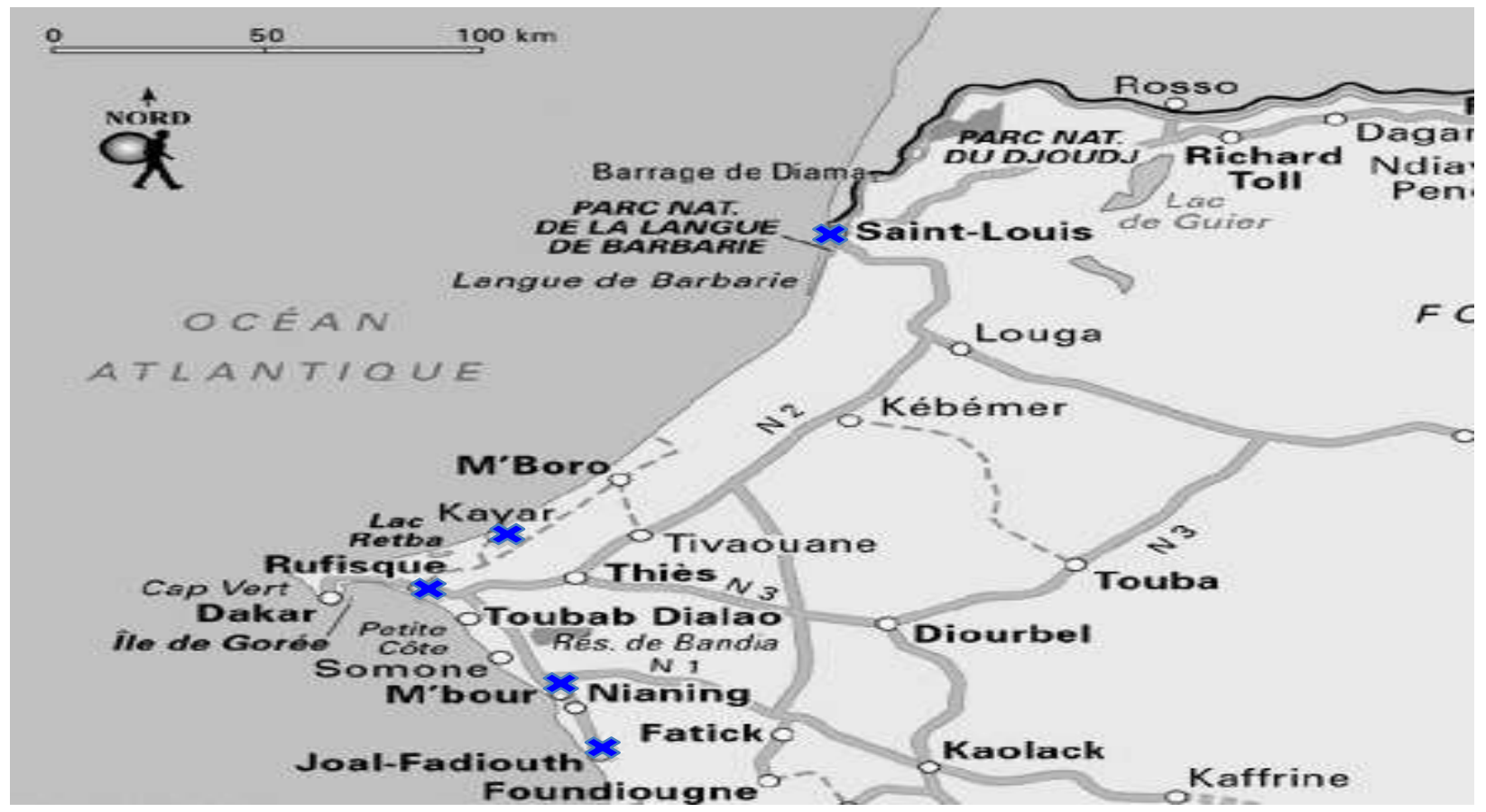

Map 1:- Location of sites sampling (Source: https://www.routard.com/guide_carte/code_dest/senegal.htm modified by Mbaye). 
Each sample consisted of three fish (full sardinella) taken at random from a hazardously selected processor in a group called GIE (Economic Interest Grouping). The ketiakh was prepared from Sardinella aurita and/or Sardinella maderensis, braised or smoked, headed, gutted, scaled and sprinkled with salt or not and then dried (photos 1, and 2). Each sample was wrapped immediately with aluminium foil and kept in a sealed plastic bag in a cool place until it was sent to Belgium for residue analysis.

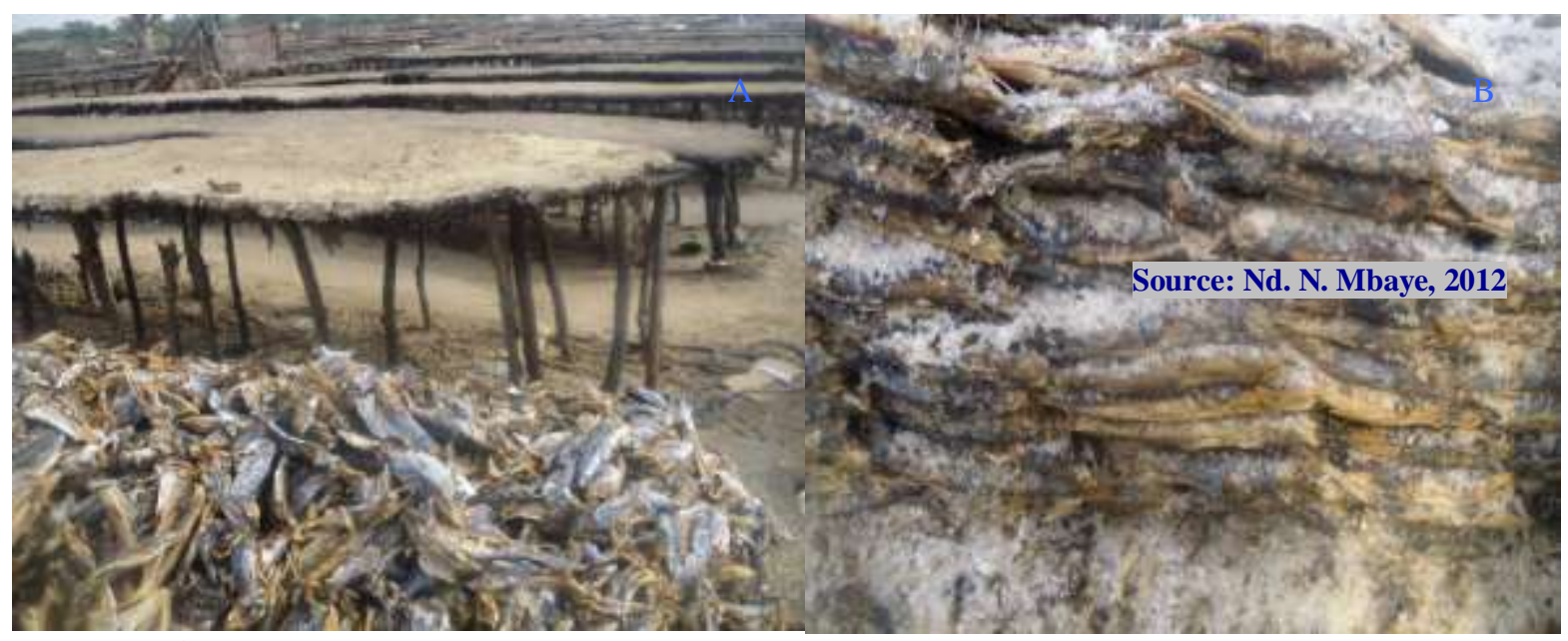

Photo 1:- Drying of Sardinella aurita and Sardinella maderensis, smoked without salt (A) and with salt (B) at Khelcome (Thies).

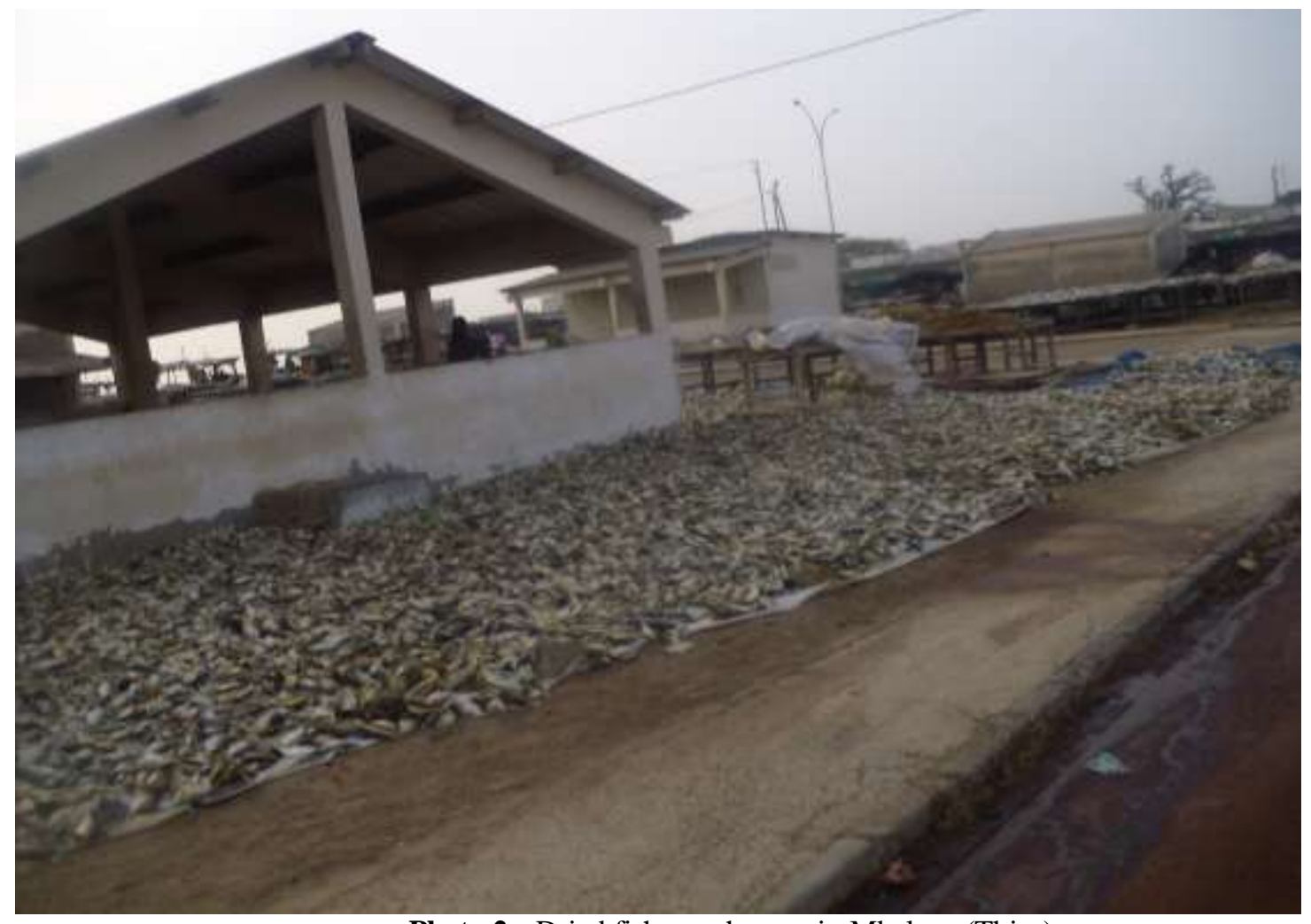

Photo 2:- Dried fish warehouses in Mbalene (Thies).

\section{Residue analysis:}

Analyses of the 25 samples of ketiakh were performed by the PRIMORIS laboratory (Technologiepark 2/3, 9052 Zwijnaarde, Belgium), accredited according to ISO/IEC 17025 for residue analysis in foodstuffs. The analyses were performed by combining two in-house methods (GMS2 and GMS3) validated for the measurement of pesticide 
residues (screening of 148 active substances, including organophosphorus and pyrethroid insecticides) in high fat matrices (vegetable oils, coconut, cocoa, meat, fish, milk, etc). After sub-sampling followed by grinding, the samples were submitted to apolar extraction followed by column purification, gas chromatographic analysis and residue identification by GC-MS/MS. The limit of quantification (LOQ) for each of the 148 substances was 0.01 $\mathrm{mg} / \mathrm{kg}$. It should be noted that there is no minimum residue limit (MRL) for dried fish.

\section{Assessment of risk from predicted short-term intake (PSTI):}

Consumer exposure can theoretically be calculated from the estimated consumption (in g/day) and the observed residue concentration (in $\mathrm{mg} / \mathrm{kg}$ ) relative to the mean body weight (in $\mathrm{kg}$ ) (WHO, 1997). However, it is preferable to estimate the intake of a given pesticide residue during a meal (or a day) by referring to the predicted short term intake (PSTI) calculation methods currently in use in the European Union. To characterize the risk, the PSTI values are compared with the toxicological reference values for each substance: the acute reference dose (ARfD), which is the most relevant; and the acceptable daily intake (ADI), which should be considered with caution in cases of acute exposure. The formula adopted for calculation of the PSTI $(\mathrm{mg} / \mathrm{kg})$ is the following (AFSCA, 2014; Schiffers, 2011):

PSTI

$$
\frac{([\mathrm{U} \cdot \mathrm{OR}+\mathrm{V})+(\mathrm{LP} \quad \mathrm{Oj}+\mathrm{OR})=\mathrm{C}}{\text { bwe }}
$$

Where:

$\mathbf{U}=$ unit (food unit weight) in $\mathrm{kg} ; \mathbf{O R}=$ observed residue, in $\mathrm{mg} / \mathrm{kg}$ (or ppm); $\mathbf{V}=$ variability factor $=0 ; 5$ or 7 (chosen according to $\mathrm{U}$ ); $\mathbf{t}$ = processing factor (1 if unknown); $\mathbf{b w}=$ body weight of the group in question

The unit weight (U) of smoked-dried sardinella (ketiakh) and the percentile of the large consumers LP97.5 were obtained using data from an interview survey conducted in Senegal and published by the IRD in Montpellier, with the calculation of the weight of the ingredients from the overall mass of the dish and the consumption of $1000 \mathrm{~g}$ of ketiakh daxin (Dop et al., 2003). For the bw body weight of an adult or a child, the English data were used: Mean Body Weights and Age Distributions for Countries Reporting 97.5th Percentile Consumption, GEMS/Food (Schiffers, 2011) because they are close to the body weight measurements taken in Senegal (Kirsten et al., 1991). The variability factor $(\mathrm{V})=7$ if $25<\mathrm{U}<250 \mathrm{~g}$ and the processing factor $\mathrm{t}=1$ by default (AFSCA, 2014; Schiffers, 2011); the values of residue concentrations (OR) of the insecticides detected for each sample were used. The PSTI for adults and children was obtained by incorporating the values in table 1 into the formula.

Table 1:- Values used to calculate the PSTI.

\begin{tabular}{|l|l|l|l|}
\hline & Values & Units & Sources \\
\hline $\begin{array}{l}\text { OR (observed residue } \\
\text { of insecticides measured) }\end{array}$ & variable & $\mathrm{mg} / \mathrm{Kg}$ & PRIMORIS analysis \\
\hline ADI of the active substance & variable & $\mathrm{mg} / \mathrm{Kg} \mathrm{bw} / \mathrm{d}$ & $\mathrm{EU}, 2019$ \\
\hline ARfD of the active substance & variable & $\mathrm{mg} / \mathrm{Kg}$ bw/d & EU, 2019 \\
\hline Unit weight of ketiakh & 0.033 & $\mathrm{Kg}$ & Dop et al., 2003 \\
\hline LP 97,5 th of ketiakh & 1.826 & $\mathrm{Kg} / \mathrm{Kg}$ bw/d & Dop et al., 2003 \\
\hline Variability factor & 7 & Unitless & Schiffers, 2011 \\
\hline Transformation factor & 1 & Unitless & Schiffers, 2011 \\
\hline bw adult & 70 & $\mathrm{Kg}$ & Kirsten et al., 1991 \\
\hline bw child & 20 & $\mathrm{Kg}$ & Kirsten et al., 1991 \\
\hline
\end{tabular}

\section{Results:-}

\section{Results of residue analyses of the samples of ketiakh taken:}

The results of the analysis provided by the PRIMORIS laboratory (Belgium) of the 25 samples of smoked-dried Sardinella aurita and Sardinella maderensis (ketiakh) from sites in the regions of Dakar, Thies and Saint-Louis: are presented in table 3. Residues of chlorpyrifos (organophosphorus) and cypermethrin (pyrethroid) were found to be above the LOQ in the samples from Dakar and Thies. Fenitrothion (organophosphorus) was found in only one of the samples from Thies (tables 2 and 3). Residues in all five samples from the Saint-Louis region were below the LOQ of $0.01 \mathrm{mg} / \mathrm{kg}$ (table 2). 
Table 2:- Results of pesticide residue analysis by PRIMORIS (Belgium).

\begin{tabular}{|c|c|c|c|c|c|}
\hline Matrix & Region & $\begin{array}{l}\text { Weight } \\
\text { of sample } \\
\text { taken }(\mathrm{g})\end{array}$ & $\begin{array}{l}\text { Active substance } \\
\text { quantified }\end{array}$ & Chemical family & $\begin{array}{l}\text { Residue } \\
\text { content } \\
\text { (mg/Kg) }\end{array}$ \\
\hline \multirow{27}{*}{$\begin{array}{l}\text { Ketiakh: Smoked } \\
\text { and dried } \\
\text { Sardinella aurita } \\
\text { and/or Sardinella } \\
\text { maderensis }\end{array}$} & \multirow{6}{*}{ Dakar } & 207.1 & $<\mathrm{LOQ}$ & & - \\
\hline & & \multirow[t]{2}{*}{183.5} & Chlorpyrifos & Organophosphorus & 0.099 \\
\hline & & & Cypermethrin & Pyrethroid & 0.042 \\
\hline & & 166.2 & Chlorpyrifos & Organophosphorus & 0.014 \\
\hline & & 140.8 & $<\mathrm{LOQ}$ & & - \\
\hline & & 193.9 & $<\mathrm{LOQ}$ & & - \\
\hline & & 226.9 & $<\mathrm{LOQ}$ & & - \\
\hline & & & Chlorpyrifos & Organophosphorus & 0.310 \\
\hline & & & Cypermethrin & Pyrethroid & 0.045 \\
\hline & & 160.1 & Chlorpyrifos & Organophosphorus & 0.120 \\
\hline & Thies & 206.1 & $<\mathrm{LOQ}$ & & - \\
\hline & & 175.6 & Fenitrothion & Organophosphorus & 0.022 \\
\hline & & 170.1 & $<\mathrm{LOQ}$ & & - \\
\hline & & 186.0 & $<\mathrm{LOQ}$ & & - \\
\hline & & 224.3 & $<\mathrm{LOQ}$ & & - \\
\hline & & 252.2 & $<\mathrm{LOQ}$ & & - \\
\hline & & 286.5 & $<\mathrm{LOQ}$ & & - \\
\hline & & 252.2 & $<\mathrm{LOQ}$ & & - \\
\hline & & 216.5 & $<\mathrm{LOQ}$ & & - \\
\hline & & 156.3 & $<\mathrm{LOQ}$ & & - \\
\hline & & 197.0 & $<\mathrm{LOQ}$ & & - \\
\hline & & 75.4 & $<\mathrm{LOQ}$ & & - \\
\hline & & 310.5 & $<\mathrm{LOQ}$ & & - \\
\hline & Saint-Louis & 295.5 & $<\mathrm{LOQ}$ & & - \\
\hline & & 279.4 & $<\mathrm{LOQ}$ & & - \\
\hline & & 326.3 & $<\mathrm{LOQ}$ & & - \\
\hline & & 293.9 & $<\mathrm{LOQ}$ & & - \\
\hline
\end{tabular}

$<\mathrm{LOQ}=$ the result is below the quantification limit of the method

Table 3:- Pesticides detected and quantified in samples of ketiakh $(\mathrm{mg} / \mathrm{kg})$.

\begin{tabular}{|l|l|l|l|l|}
\hline Region/site & $\begin{array}{l}\text { Weight } \\
\text { of sample } \\
\text { taken }(\mathrm{g})\end{array}$ & $\begin{array}{l}\text { Chlorpyrifos } \\
\text { organophosphorus } \\
(\mathrm{mg} / \mathrm{Kg})\end{array}$ & $\begin{array}{l}\text { Cypermethrin } \\
\text { pyrethroid } \\
(\mathrm{mg} / \mathrm{Kg})\end{array}$ & $\begin{array}{l}\text { Fenitrothion } \\
\text { organophosphorus } \\
(\mathrm{mg} / \mathrm{Kg})\end{array}$ \\
\hline Dakar/DGB & 183.5 & 0.099 & 0.042 & - \\
\hline Dakar/DGB & 166.2 & 0.014 & - & - \\
\hline Thies/Mbalene & 216.0 & 0.310 & 0.045 & - \\
\hline Thies/Mbalene & 160.1 & 0.120 & - & \\
\hline Thies/Mbalene & 175.6 & - & - & 0.022 \\
\hline
\end{tabular}

DGB $=$ Diamagueune-Bata

Predicted short-term intake (PSTI) for an adult and child consumers:

The results of the PSTI calculation for each sample containing quantified pesticide residues are presented in tables 4 and 5. The PSTI values are compared to ARfD to estimate acute risk, and to ADI to estimate chronic risk and expressed as a percentage of the reference values. Values exceeding $100 \%$ indicate a potential risk to the consumer. 
Table 4:- PSTI values for pesticides quantified in ketiakh for the $70 \mathrm{~kg}$ group adults, and risk characterisation expressed as \%ARfD and \%ADI of each active substance.

\begin{tabular}{|c|c|c|c|c|c|c|c|c|}
\hline Region/Site & $\begin{array}{l}\text { Weight } \\
\text { of } \\
\text { sample } \\
\text { taken } \\
\text { (g) }\end{array}$ & $\begin{array}{l}\text { Active } \\
\text { substance } \\
\text { quantified }\end{array}$ & $\begin{array}{l}\text { Residue } \\
\text { content } \\
\text { (mg/Kg) }\end{array}$ & $\begin{array}{l}\text { ARfD } \\
\text { (mg/kg/ } \\
\text { bw/d) }\end{array}$ & $\begin{array}{l}\mathrm{ADI} \\
(\mathrm{mg} / \mathrm{Kg} / \\
\text { bw/d) }\end{array}$ & $\begin{array}{l}\text { PST }_{70} \\
\text { adult } \\
\text { (mg/ } \\
\text { Kg) }\end{array}$ & $\begin{array}{l}\text { PST }_{70} / \\
\text { ARfD } \\
(\%)\end{array}$ & $\begin{array}{l}\text { PSTI }_{70} / \\
\text { ADI } \\
(\%)\end{array}$ \\
\hline Dakar/DGB & 183.5 & Chlorpyrifos & 0.099 & $\begin{array}{l}0.005 \\
\text { (UE/EFS } \\
\mathrm{A}, 2014)\end{array}$ & $\begin{array}{l}0.001 \\
(\mathrm{UE} / \mathrm{EFS} \\
\mathrm{A}, 2014)\end{array}$ & 0.0290 & $580 \% *$ & $2900 \% *$ \\
\hline Dakar/DGB & 183.5 & Cypermethrin & 0.042 & $\begin{array}{l}0.04 \\
\text { (UE/JMP } \\
\mathrm{R}, 2006)\end{array}$ & $\begin{array}{l}0.02 \\
\text { (UE/JEC } \\
\text { FA, } \\
2004)\end{array}$ & 0.0012 & $3 \%$ & $6 \%$ \\
\hline Dakar/DGB & 166.2 & Chlorpyrifos & 0.014 & $\begin{array}{l}0.005 \\
\text { (UE/EFS } \\
\text { A, 2014) }\end{array}$ & $\begin{array}{l}0.001 \\
\text { (UE/EFS } \\
\text { A, 2014) }\end{array}$ & 0.0004 & $8 \%$ & $40 \%$ \\
\hline Thies/Mbalene & 216.0 & Chlorpyrifos & 0.310 & $\begin{array}{l}0.005 \\
\text { (UE/EFS } \\
\mathrm{A}, 2014)\end{array}$ & $\begin{array}{l}0,001 \\
\text { (UE/EFS } \\
\mathrm{A}, 2014)\end{array}$ & 0.0090 & $180 \% *$ & $900 \% *$ \\
\hline Thies/Mbalene & 216.0 & Cypermethrin & 0.045 & $\begin{array}{l}0.04 \\
\text { (UE/JMP } \\
\mathrm{R}, 2006)\end{array}$ & $\begin{array}{l}0,02 \\
\text { (UE/JEC } \\
\text { FA, } \\
2004)\end{array}$ & 0.0013 & $3.25 \%$ & $6.5 \%$ \\
\hline Thies/Mbalene & 160.1 & Chlorpyrifos & 0.120 & $\begin{array}{l}0.005 \\
\text { (UE/EFS } \\
\mathrm{A}, 2014)\end{array}$ & $\begin{array}{l}0.001 \\
\text { (UE/EFS } \\
\mathrm{A}, 2014)\end{array}$ & 0.0035 & $70 \%$ & $350 \% *$ \\
\hline Thies/Mbalene & 175.6 & Fenitrothion & 0.022 & $\begin{array}{l}0.013 \\
\text { (US/EFS } \\
\text { A, 2016) }\end{array}$ & $\begin{array}{l}0.005 \\
\text { (UE/EFS } \\
\mathrm{A}, 2016)\end{array}$ & 0.0006 & $4.6 \%$ & $12 \%$ \\
\hline
\end{tabular}

$*=$ Toxicological risk for the consumer

Table 5:- PSTI values for pesticides in ketiakh quantified for $20 \mathrm{~kg}$ children, and risk characterisation expressed as $\%$ ARfD and \%ADI of each active substance.

\begin{tabular}{|c|c|c|c|c|c|c|c|c|}
\hline Region/Site & $\begin{array}{l}\text { Weight } \\
\text { of } \\
\text { sample } \\
\text { taken } \\
\text { (g) }\end{array}$ & $\begin{array}{l}\text { Active } \\
\text { substance } \\
\text { quantified }\end{array}$ & $\begin{array}{l}\text { Residue } \\
\text { content } \\
(\mathrm{mg} / \mathrm{Kg})\end{array}$ & $\begin{array}{l}\text { ARfD } \\
\text { (mg/kg/ } \\
\text { bw/d) }\end{array}$ & $\begin{array}{l}\text { ADI } \\
\text { (mg/Kg/ } \\
\text { bw/d) }\end{array}$ & $\begin{array}{l}\text { PSTI }_{20} \\
\text { child } \\
\text { (mg/ } \\
\text { Kg) }\end{array}$ & $\begin{array}{l}\text { PSTI }_{20} / \\
\text { ARfD } \\
(\%)\end{array}$ & $\begin{array}{l}\text { PSTI }_{20} / \\
\text { ADI } \\
(\%)\end{array}$ \\
\hline Dakar/DGB & 183.5 & Chlorpyrifos & 0.099 & $\begin{array}{l}0.005 \\
\text { (UE/EFS } \\
\mathrm{A}, 2014)\end{array}$ & $\begin{array}{l}0.001 \\
(\mathrm{UE} / \mathrm{EFSA} \\
, 2014)\end{array}$ & 0.1015 & $\begin{array}{l}2030 \% \\
*\end{array}$ & $\begin{array}{l}\mathbf{1 0 1 5 0 \%} \\
*\end{array}$ \\
\hline Dakar/DGB & 183.5 & Cypermethrin & 0.042 & $\begin{array}{l}0.04 \\
\text { (UE/JMP } \\
\mathrm{R}, 2006) \\
\end{array}$ & $\begin{array}{l}0.02 \\
(\mathrm{UE} / \mathrm{JECF} \\
\mathrm{A}, 2004)\end{array}$ & 0.0042 & $10.5 \%$ & $21 \%$ \\
\hline Dakar/DGB & 166.2 & Chlorpyrifos & 0.014 & $\begin{array}{l}0.005 \\
\text { (UE/EFS } \\
\text { A, 2014) }\end{array}$ & $\begin{array}{l}0.001 \\
(\mathrm{UE} / \mathrm{EFSA} \\
, 2014)\end{array}$ & 0.0014 & $28 \%$ & $140 \% *$ \\
\hline Thies/Mbalene & 216.0 & Chlorpyrifos & 0.310 & $\begin{array}{l}0.005 \\
\text { (UE/EFS } \\
\mathrm{A}, 2014)\end{array}$ & $\begin{array}{l}0.001 \\
(\mathrm{UE} / \mathrm{EFSA} \\
, 2014)\end{array}$ & 0.0315 & $630 \% *$ & $3150 \%$ * \\
\hline Thies/Mbalene & 216.0 & Cypermethrin & 0.045 & $\begin{array}{l}0.04 \\
\text { (UE/JMP } \\
\mathrm{R}, 2006) \\
\end{array}$ & $\begin{array}{l}0.02 \\
\text { (UE/JECF } \\
\mathrm{A}, 2004)\end{array}$ & 0.0046 & $11.5 \%$ & $23 \%$ \\
\hline Thies/Mbalene & 160.1 & Chlorpyrifos & 0.120 & 0.005 & 0.001 & 0.0123 & $246 \% *$ & $1230 \% *$ \\
\hline
\end{tabular}




\begin{tabular}{|l|l|l|l|l|l|l|l|l|}
\hline & & & & $\begin{array}{l}\text { (UE/EFS } \\
\text { A, 2014) }\end{array}$ & $\begin{array}{l}\text { (UE/EFSA } \\
, 2014)\end{array}$ & & & \\
\hline Thies/Mbalene & 175.6 & Fenitrothion & 0.022 & $\begin{array}{l}0.013 \\
\text { (US/EFS } \\
\text { A, 2016) }\end{array}$ & $\begin{array}{l}0.005 \\
\text { (UE/EFSA } \\
, 2016)\end{array}$ & 0.0021 & $16.2 \%$ & $42 \%$ \\
\hline
\end{tabular}

* = Toxicological risk for the consumer

\section{Discussion:-}

The determination of pesticide residues, apart from the direct evaluation of the residue study, is an integral part of the risk assessment process, making explicit the continued likelihood of exposure and ensuring that accepted daily intakes are not exceeded (Abhauer, 1990; Blasco et al., 2005). Following the initial study of Mbaye et al. (2012), which indicated the presence of some of the most hazardous pesticide residues (parathion, pirimiphos-methyl, chlorpyrifos, lindane, permethrin and dieldrin) in ketiakh from the sites of Mbalene, Khelcome and Kayar, the search for pesticide residues was extended to other sites, the number of samples was multiplied by ten, and the number of active substances searched for was increased. For this study, sampling was carried out over the entire coastline, with sites in the regions of Saint-Louis, Dakar and Thies. The analytical methods used made it possible to search for 148 residues in each sample.

The residue concentrations measured are high, and confirm the results of the study by Mbaye et al. (2013) at the Mbalene and Khelcome sites. The presence of two organophosphorus insecticides and a pyrethroid is of concern in light of the toxicity of these compounds to the nervous system. Measured values of chlorpyrifos, cypermethrin and fenitrothion in samples of ketiakh from the Dakar and Thies regions (tables 2 and 3) indicate that pesticides are applied to processed products without any measurement, when insects proliferate, insecticide powder is mixed with the rock salt applied. Processors use any pesticide that vendors advertise as Kaata. For example, parathion, pirimiphos-methyl, chlorpyrifos, permethrin and even dieldrin have been detected and quantified previously. In the region of Saint-Louis, the site of Guet Ndar, the residue values were below the LOQ of the method for the 148 molecules analyzed. Given the sensitivity of the analytical methods used, this probably means that these processors did not use pesticides. On some occasions, the PSTI values obtained for adults and children were 10,000\% higher than the ARfD or ADI values (tables 4 and 5). These results indicate that adult consumers of these processed products, and especially the much more vulnerable juvenile consumers, are at high risk of acute and chronic intoxication (COLEACP/PIP, 2010). The health effects of exposure to these neurotoxic insecticides have been the subjects of numerous publications around the world (Baldi et al., 2011; Crofton et al., 2005; Ondine et al., 2019; Slothkin et al., 2006).

\section{Case of chlorpyrifos:}

Chlorpyrifos (synonyms: chlorpyrifos-ethyl, trichlormethylfos; INERIS, 2006; CPCN, 2012) was the only pesticide recovered at similar levels both in this study and in the previous tests carried out by Mbaye et al. (2012). In this study, chlorpyrifos was very recurrent at fairly high residual values at the Dakar and Thies sites (table 3). For chlorpyrifos, the estimation of PSTI for adults of $70 \mathrm{~kg}$ and children of $20 \mathrm{~kg}$ gave values exceeding the ADI and ARfD of chlorpyrifos by $100 \%$ in almost all samples (tables 4 and 5). Therefore, in terms of exposure, these samples of ketiakh constitute both a chronic and acute intoxication risk for adult and especially juvenile consumers, as the toxicological risk is considered unacceptable for the consumer if the PSTI is higher than the toxicological reference value (COLEACP/PIP, 2010). These toxicological risks constitute a real public health concern because chlorpyrifos can cause long-term neurotoxic and endocrine-disrupting effects (Baldi et al., 2011; PPDB, 2019); can affect the development of the central nervous system (Slothkin et al., 2006); and is also known to affect endocrine secretion (Wilson, 1998). Chlorpyrifos is highly toxic when ingested in children, and some studies indicate an association between chlorpyrifos metabolites and learning disabilities (autism) in children (Ondine et al., 2019; PPDB, 2019; Whyatt et al., 2003). This is why representatives of EU member states voted to ban chlorpyrifos and chlorpyrifosmethyl in December 2019 (Actu-Envi, 2020).

\section{Cases of cypermethrin and fenitrothion:}

Cypermethrin was quantified in two samples from Dakar and Thies; it should be noted that these two samples also contained chlorpyrifos. With respect to the calculation of the PSTI 70 and $\mathrm{PSTI}_{20}$, the comparison with the ADI and ARfD of cypermethrin resulted in percentages of less than 100\% (tables 4 and 5), suggesting that these samples of ketiakh did not pose a risk to adult and child consumers. However, because these two samples from Dakar and Thies each contained both an organophosphorus and a pyrethroid, consumers would experience a "cocktail effect" of these 
two insecticides in addition to the already toxic effect of chlorpyrifos. The "cocktail effect" is important: although exposure to some potentially hazardous chemicals may be below individual thresholds for adverse effects, cumulative exposure to several of these substances, even at low levels, may be harmful to vulnerable groups (Crofton et al., 2005; Greenlee et al., 2003; Heudorf et al., 2004; Infante-Rivard, et al., 1999; Provost et al., 2007). Simply put, zero risk does not exist in these cases.

Fenitrothion, on the other hand, was detected and quantified in only one sample from Thies, where the PSTI calculated and compared to the ADI and ARfD of the latter, gave only percentages below $100 \%$ for both adult and child consumers. Therefore fenitrothion represents neither a chronic nor an acute risk for the exposure of consumers of ketiakh (adults and children) from these sites as the PSTI values were all below the ADI and ARfD values.

\section{Conclusion:-}

The presence of pesticide residues in foodstuffs is a serious public health problem and gives rise to legitimate consumer concern. As the use of plant protection products on processed fish products is neither usual nor recommended practice, there are no MRLs for these commodities. However, it must be noted that this dangerous and illegal practice has spread in Senegal and continues to this day because these products are easily accessible to processors. Unaware of the adverse health consequences for consumers, processors indiscriminately use neurotoxic substances (chlorpyrifos, cypermethrin and fenitrothion), which can cause immediate intoxication after consumption of the dish. In the longer term, repeated exposure to these substances can also cause, especially in children, many pathologies such as cancer of hormone-dependent organs (breast, prostate, testicles, ovaries or thyroid), but also disorders of the reproductive organs (infertility) and brain development disorders, as they are known to act as endocrine disruptors. It is therefore strongly recommended that the Senegalese authorities raise awareness among the population, both processors and consumers, of the risks associated with pesticide use in ketiakh production, and seek alternative solutions to protect fishery products against attacks by Dermestes.

\section{Acknowledgements:-}

The authors would like to thank the Phytopharmacy Laboratory, Gembloux Agro-BioTech/ULiege (Belgium) for having financing the analyses of pesticide residues at the PRIMORIS laboratory (ex FYTOLAB) in Belgium.

\section{References:-}

1. Abhauer J. (1990): Pesticide residues-Determination and evaluation in food and environment, in Pesticide chemistry, VCH, New York, 361-372.

2. Actu-Envi (2020): Actu-Environnement. Pesticides: l'Europe interdit le chlorpyrifos: par Radisson L., journaliste-rédacteur en chef délégué aux marchés HSE. Actu-Environnement.com/https://www.actuenvironnement.com/ae/news/europe-interdiction-chlorpyrifos 34570.php4

3. AFSCA (2014): Agence Fédérale pour la Sécurité de la Chaîne Alimentaire. Inventaire des actions et des limites d'action et propositions d'harmonisation dans le cadre des contrôles officiels: contaminants chimiques, résidus et additifs. Version 5 - Mars 2014, 68 p.

4. ANSD (2009): Agence National de la Statistique et de la Démographie. Situation économique et sociale de la région de Dakar de l'année 2008. Service Régional de la Statistique et de la Démographie (SRSD) de Dakar. Ministère de l'Economie et des Finances du Sénégal. Edition 2008, 186 p.

5. ANSD (2010): Agence National de la Statistique et de la Démographie. Situation économique et sociale de la région de Saint -Louis. Service Régional de la Statistique et de la Démographie

(SRSD) de Saint -Louis. Ministère de l'Economieet des Finances du Sénégal Edition 2009, 133 p.

6. Baldi I., Gruber A., Rondeau V., Lebailly P., Brochard P. and Fabrigoule C. (2011): Neurobehavioral effects of long-term exposure to pesticides: results from the 4-year follow-up of the PHYTONER study. Occup Environ Med 2011; 68:108-115.

7. Blasco C., Font G., Manes J. and Pico Y. (2005): Screening and evaluation of fruit samples for four pesticide residues. Journal of AOAC international, 88, 3, 84.

8. COLEACP/PIP (2010): Risk analysis and control in production. COLEACP-PIP training manuals: Manuel_3_UK_pp. COLEACP/PIP, Rue du Trône, 130 B- 1050 Brussels-Belgium /PDF, 150 p.

9. CPCN (2012): Compendium of Pesticide Common Names. Data sheets for new ISO common names are normally added within 2-3 weeks after provisional approval by ISO Technical Committee 81 , which is responsible for ISO $1750 / \mathrm{http}: / / w w w . a l a n w o o d . n e t / p e s t i c i d e s$ 
10. Crofton K.M., Craft E.S., Hedge J.M., Gennings C., Simmons J.E., Carchman R.A., Hans Carter W. and DeVito M.J. (2005): Thyroïd hormone disrupting chemicals: Evidence for dose dependent additivity or synergism. Environmental Health Perspectives, 113: 1549-54.

11. Dop Marie-Claude, Gomis Marie-Claire, Gourdom Muriel and Lessauvage Stéphane (2003): Estimation faite sur le terrain à Pikine: recette quantitative: proportions d'ingrédients. Outil d'enquête alimentaire: poisson et mollusques. Dans Outil d'enquête alimentaire par entretient. IRD Edition, 2003, 225p. ISBN: 2-7099-1535-9. ISSN: 1142-2580. IRD de Montpellier 911 avenue Agropolis PB 64501-34394 Montpellier cedex 5.

12. EU (2019): European Union-Pesticides databases/VTR. Database consulted during the research in 2019/http://ec.europa.eu/sanco_pesticides/public/index.cfm

13. FAO (1981): The prevention of losses in cured fish. FAO Fisheries Technical Paper, 219 : 87 p. Rome, Italy: Food and Agriculture Organization

14. Greenlee AR., Arbuckle TE. and Chyou P-H. (2003): Risk factors for female infertility in an agricultural region. Epidemiol Camb Mass 2003; 14:429-436.

15. GRET (2005): Groupe de Recherche et d'Echanges Technologiques : Etat des lieux de la de la filière de transformation artisanale des produits halieutiques au Sénégal réalisé par Mbaye L., dans le cadre d'une association entre le Projet d'accès à l'information et au conseil pour les micro et petites entreprises agroalimentaires (InfoConseil MPEA) et le projet d'appui aux operateurs/trices de l'agroalimentaire (PAOA). Décembre 2005, 40 p.

16. Gueye-Ndiaye A. and Marchand (1989): Lardoglyphus konoi et Suidasia ponctifia, déprédateurs des sardinelles braisées-séchées au Sénégal. Acarologia, 30(2): 131-137.

17. Heudorf U., Angerer J. and Drexler H. (2004): Current internal exposure to pesticides in children and adolescents in Germany: urinary levels of metabolites of pyrethroid and organophosphorus insecticides. Int Arch Occup Environ Health 77(1) : 67-72.

18. INERIS (2006): Institut National l'EnviRonnement Industriel et des riSques. Données technico-économiques sur les substances chimiques en France: le chlorpyriphos-éthyle, par Brignon J.M. et Gouzy A. Dernière mise à jour: 29/03/2006, 14 p.

19. Infante-Rivard C., Labuda D., Krajinovic M. and Sinnet D. (1999); Risk of childhood leukemia associated with exposure to pesticides and with gene polymorphisms. Epidemiology, 10(5): 481-487.

20. Kirsten B. Simondon, Eric Bénéfice, François S., Valérie D. and Anouch C. (1991): Seasonal variation in nutritioal status of adults and children in Senegal. Seasonaly and Human Ecologie. Edition S. J. Ulijaszek \& S. S. Strickland. Doc. ORSTOM

21. Mbaye Ndeye Ndiabe, Sarr M., Gueye-Ndiaye A., Samb A. and Sembene Mbacke (2012): Identification and Quantification of Synthetic Insecticides Used Against Pests Smoked-Dried Fish in Senegal: Risk Assessment. International Journal of Science and Advanced Technology, 13(2): 73-80.

22. Mbaye Ndeye Ndiabe, Sarr M., Tine E., Samb A. and Sembene Mbacke (2013): Pattern of using pesticides against pests of halieutic products in the Thies region, department of Mbour, Senegal. South Asian Journal of Experimental Biologie, 3(3): 106-112.

23. Ondine S. von Ehrenstein, Chenxiao Ling, Xin Cui, Myles Cockburn, Andrew S. Park, Fei Yu, Jun Wu and Beate Ritz (2019): Prenatal and infant exposure to ambient pesticides and autism spectrum disorder in children: population based case-control study. BMJ 2019; 365 doi: https://doi.org/10.1136/bmj.14032

24. PPDB (2019): Pesticides Properties DataBase: Databases of PPDB. University of Hertfordshire/ http://sitem.herts.ac.uk/aeru/footprint/index2.htm

25. Provost D., Cantagrel A., Lebailly P., Jaffré A., Loyant V., Loiseau H., Vital A., Brochard P. and Baldi I. (2007): Brain tumours and exposure to pesticides: a case-control study in southwestern France. Occup Environ Med 2007; 64:509-514

26. Schiffers Bruno (2011): Eude de cas résidus de pesticides. Prof. Schiffers Training Unit, Cellule de Formation bruno.schiffers@ulg.ac.be-COLEACP/PIP: Rue du Trône, 130 B- 1050 Bruxelles - Belgique. Tél. + 32.2.508.10.90 pip@coleacp.org.

27. Slothkin T.A., Levin E.D. and Seidler F.J. (2006): Comparative developmental neurotoxicity of organophosphate insecticides: Effects on brain development are separable from systemic toxicity. Environ. Health Perspect. 114: 746751.

28. Sembene Mbacke (1994): Effets de la teneur en eau et de la teneur en sel du poisson fermenté-séché sur son degré d'infestation par Dermestes sp (Coléoptèra-Dermestidae). Mémoire de DEA à la Faculté des Sciences et Techniques. Université Cheikh Anta Diop de Dakar. 
29. Watanabe M.K. (1974): Technologie et hygiène des méthodes de préparation du poisson salé-séché fabriqué en Afrique avec référence spéciale au Ghana, au Sénégal et à la Zambie. Doc. PNUD.FAO. (I.T.A) Dakar (Sénégal).

30. WHO (1997): Guideline for predicting dietary intake of pesticide residue (revised). Prepared by the Global Environment Monitoring System - Food Contamination Monitoring and Assessment Programme (GEMS/Food) in collaboration with the Codex Committee on Pesticide Residues. WHO, Geneva (CH), 33p.

31. Whyatt RM., Barr DB., Camann DE., Kinney PL., Barr JR., Andrews HF., Hoepner LA., Garfinkel R., Hazi Y., Reyes A., Raminez J., Cosme Y. and Perera FP. (2003) : Contemporary-use pesticides in personal air samples during pregnancy and blood samples at a delivery among urban minority mothers and newborns. Environmental Health Perspectives, vol. 111, no. 5: 749-56.

32. Wilson, HA. (1998): Developmental neurotoxicology of endocrine disruptors and pesticides: Identification of information gaps and research needs. Environmental Health Perspectives 106, Suppl. 3: 807-811. 